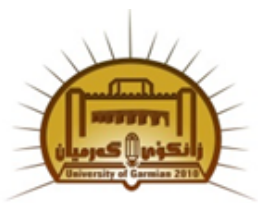

Available online at http://jgu.garmian.edu.krd

Journal of Uni versity of Garmian

https://doi.org/10.24271/garmian.1050

\title{
Intestinal and Ectoparasites of black rats (Rattus rattus) in Garmian, Kurdistan region of Iraq
}

\author{
Omer Mahmood Amin \\ Department of Biology, College of Education, University of Garmian
}

\section{Article Info}

Received: March, 2019

Revised: March,2019

Accepted: March,2019

\section{Keywords}

Intes tinal parasites, Ectoparasites, Rattus rattus, Garmian region, Iraq

\section{Corresponding Author}

omer.mahmood@garmian.edu.krd

\begin{abstract}
Rodents are found worldwide and live close to human inhabitation. They are known as vectors of zoonotic diseases such as viral, bacterial and parasitic infections. Investigating parasites of rats and understanding their life cycles have become crucial necessity. The present study aimed to screen for the presence of intestinal parasites and ectoparasites in black rats (Rattus rattus) in Garmian region. An overall 55 live rats (21 male, 34 female) were trapped from three districts in Garmian region (Kalar, Kifri and Khanaqin). The rats were euthanized, dissected and their parasites were identified. The overall rate of infection with at least one parasite was $61.81 \%$ (36/55). Four genera of nematodes were identified; Trichuris muris, Capillaria sp., Strongyloides $s p$. and Trichostrongylus sp. with infection rate 20\% (11/55). Twenty four out of the 55 rats $(43.63 \%)$ were infected with Hymenolepis nana and/or Hymenolepis diminuta. Three protozoa were also identified, Giardia muris, Entamoeba muris and Isospora ratti with infection rate of $25.45 \%(14 / 55)$. The flea Xenopsylla cheopis was the only ectoparasite identified from 4 rats (7.27\%). Rat from all the three studied areas carried parasites with no significant difference in term of infection rates. Male rats showed significantly higher prevalence of parasites compared to female. Coinfection was observed in rats and some rats carried four types of parasites at one time. Findings of this study suggest that rats of Garmian region harbor zoonotic parasites which can pose risk to humans and animals. Therefore, actions have to be taken to content the potential of disease transmission.
\end{abstract}

\section{Introduction}

Rodents are the most abundant mammals in the world, they inhabit all the continents except the Antarctica and comprise more than one-third of all mammals on earth (Parshad, 1999). Black rat (Rattus rattus) sometimes called house rat or ship rat is a medium sized and long tailed rodent with dark grey color belong to the order rodentia. These small mammals have the ability to adapt to a wide variety of habitats such as wall cavities and false ceilings of buildings whereas in the wild, black rats live in cliffs, rocks, the ground, and trees (Franssen et al., 2016; Majeed, 2016). As a result of that and in addition to their omnivorous feeding nature, rats are known to carry viruses, bacteria and parasites (Singleton $e t$ al., 2003). Changing in ecosystems, establishing new urban areas and increasing human populations are directly related in the increase of rat transmitted diseases (Terraube, 2015). Rats represent a perfect reservoir host for veterinary importance parasites than can cause serious hazards to livestock and human (Sharma et al., 
2013). Endoparasites such as Hymenolepis nana, H. diminuta, Capillaria sp., Trichuris muris, Strongyles and coccidia are the most common and are transmitted mainly through the rat excrement (Pakdel et al., 2013 Meshkekar et al., 2014). In addition, rats can carry ectoparasites such as fleas, flies, ticks and lice which can also feed on other animal or human blood and therefore transmit various diseases (Soliman et al., 2001). Since rats are important vector of parasite transmission and because of their close habitat to human, it is crucial to explore rat parasites in various places of Iraq. Although, there are some epidemiological studies carried out on rat parasites in some areas of Iraq such as Missan, Baghdad and Kufa (Al-Ali and Jabbr, 2006; Karim and Al-Salihi, 2014; Majeed, 2016; Nayyef, 2017), little is known about parasite prevalence and rat zoonotic parasites in Garmian region. The present study aims to screen for intestinal parasites and ectoparasites in black rat (Rattus rattus) in three main districts of Garmian region (Kalar, Kifri and Khanaqin).

\section{Materials and Methods}

In this study 55 black rats (Rattus rattus) (21 male and 34 female) were trapped using cage trap baited with cheese, bread and date from center of three districts (Kifri, Kalar and Khanaqin) in Garmian region and the villages around from the period of December 2017 to February 2019 (Figure 1). The rats were trapped at night from different places such as old buildings, farms, garbage and drains. Trapped rat were immediately transferred to the research labs in Garmian University where humanly euthanized using absolute ether. Euthanized rats were searched for ectoparasites using brushes and fine toothed combs. After that, the rats were dissected, their intestines were placed in warm normal saline and longitudinally cut then the fecal contents were taken from different locations (Al-Bajalan, 2018). Fecal samples were examined for the existence of cysts, oocysts and helminthes ova using direct microscopy and standard salt floatation technique (Yokohata, 1989). The helminthes were preserved in $70 \%$ ethanol and stained using acetocarmine stain. Identification of the helminthes and protozoa was based on the morphological view of the adult worms, eggs, cysts and oocysts following
(Soulsby, 1986; Molan and Faraj, 2016). Chisquare test was applied in the current study for analyzing differences in infection rates using PRISM software version 6.1. Differences between variables considered significant when $P$ value was less than 0.05 .

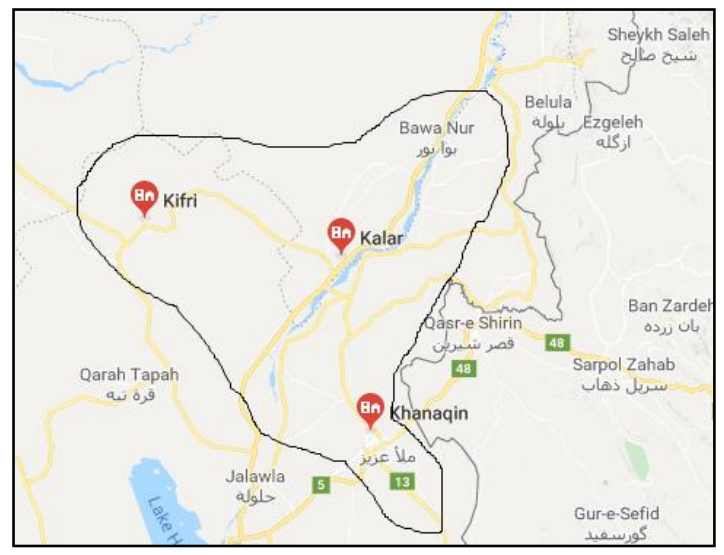

Figure 1: Sa mple collection a reas, Ka lar, Kifri and Khanaqin

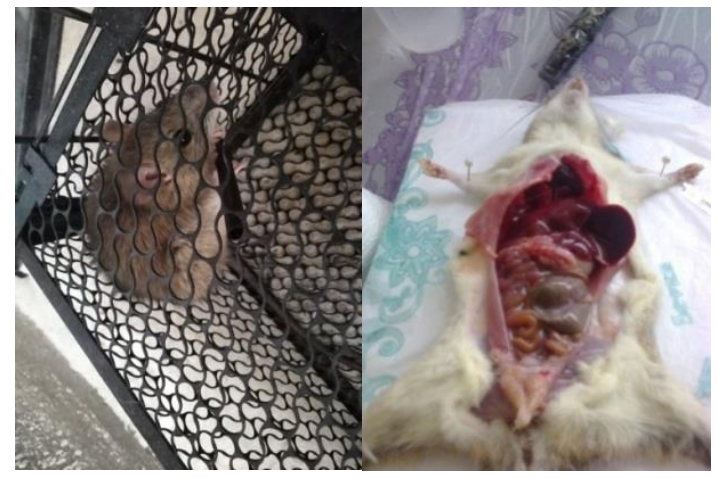

Figure 2: A fema leblack rat Rattus rattus trapped from Kalar district using ca ge tra $p$

\section{Results}

Out of the 55 live trapped black rats, 24 were male and 31 female. The overall prevalence of parasites in rats was $61.81 \%(36 / 55)$ Table 2. Ten genera of parasites were identified in rats as follows: four nematodes; Trichuris muris (3.63\%), Capillaria sp. (3.63\%), Strongyloides sp. (14.55\%) and Trichostrongylus sp. (1.81\%). Two species of cestode were also identified; Hymenolepis nana $(21.81 \%)$ and $H$. diminuta $(32.72 \%)$. Three protozoa; Isospora ratti (12.72\%), Giardia muris $(5.45 \%)$ and Entamoeba muris $(9.1 \%)$. One species of ectoparasite, the flea Xenopsylla cheopis was observed in four rats $(7.27 \%)$, (Table 1$)$. The highest rate of infected rats were trapped from 
Kifri $70 \%(14 / 20)$ and the lowest rate was in Khanaqin 52.94\% (9/17) and there was no significant differences between infection rates in the investigated areas $\mathrm{P}>0.05$ (Table 2). Males were significantly more infected with parasites $83.33 \%$ (20/24) than that of female 41.93 (13/31) $\mathrm{P}<0.05$ (Table 3 ). Some rats were infected with a single parasite while others were infected with more than one parasite and the highest parasite types identified in one rat was four.

\section{Discussion}

Rodents, particularly rats play an important role as reservoir host for zoonotic diseases. The present study aimed to screen for endo and ectoparasites in house rats (Rattus rattus). Out of the 55 examined house rats, $34(61.81 \%)$ were infected with at least one parasitic type. Trichuris muris was observed in $3.63 \%$ of the rats. Trichuris muris has a direct life cycle and is a natural parasite of mice having the same biological and antigenic characteristics of Trichuris that infect livestock and humans (Antignano et al., 2011). There is no evidence this parasite could be zoonotic, though a study have shown that this parasite can transmit easily among different rodents (Smith and Carpenter, 2006). Pakdel et al. (2013) found that $14.49 \%$ of Rattus norvegicus and Mus musculus were infected with T. muris when they conducted their study in Iran. Lower rate of infection of black rats with T. muris $(2.32 \%)$ was observed in India (Sharma et al., 2013). The presence of this parasite in various rodents indicates that the parasite is cosmopolitan. Capillaria sp. was also observed in the current study with a rate of infection (3.63\%). Siti Shafiyyah (2012) reported six genera of parasites in wild rats in Kuala Lumpur-Malaysia and the rate of Capillaria hepatica was $13.9 \%$. In Tehran-Iran, Meshkekar et al. (2014) reported that $1.7 \%$ of the studied black rats were infected with Capillaria annulosa. Rats were infected with different Strongyle nematodes with unidentified species (14.55\%). Kia et al. (2001) reported in their study of the rodent parasites in Ahvaz-Iran that both $R$. rattus and $R$. norvegicus were infected with Strongylodes parasites. Cestodes showed the highest helminthes in the studied rats which were $H$. diminuta and $H$. nana. Similar studies have reported the presence of these cestodes in rodents in Iraq and some neighboring countries. Majeed (2016) reported that rats of the Iraqi capital, Baghdad collected from garbage areas carry various parasites including H.nana and H.diminuta which therefore have the potential to transmit zoonotic diseases to the nearby residence. Finding of this study agree with that of Nayyef (2017) who reported that $23.07 \%$ of rats in Baghdad and outskirts were infected with H.nana. Cestodes do not only infect house and wild rats but can be found in laboratory rodents also. Karim and Al-Salihi (2014) reported that $75 \%$ of the laboratory rats in Kufa University were infected with H.diminuta. In Garmian region, there is no data on rat parasites prevalence. However, house mice which are possible to share territories with house rats were recently reported to carry H.nana (Al-Bajalan, 2018). The high rates of infected rats with cectodes which are zoonotic parasite pose a real threat to human.

Three protozoa were recovered from rats in this study; Giardia muris, Entamoeba muris and Isospora ratti. Protozoa have direct life cycle and are transmitted through food contaminated with feces. Most protozoa are host specific, though can be of zoonotic importance. There are some studies conducted on prevalence of rat protozoa in Iraq. In term of comparison, our findings showed lower prevalence of Giardia than that conducted in Baghdad by Majeed (2016) who found that $60.31 \%$ of rats were infected with Giardia. Nayyef (2017) reported that rats were infected with Entamoeba histolytica $7.69 \%$ and Isospora sp. 31.25 respectively. In Iran, Seifollahi et al. (2016) reported high infection of rats with Giardia muris $70 \%$ and Entamoeba sp. $36.4 \%$ when carried out a study on parasites of different types of rodents in southwestern Iran. In this study, rats from all the study areas harbored parasites, this indicates that rats are excellent reservoir for pathogens. However, some parasites were identified in rats of one area and not in the others. For example, the flea Xenopsylla cheopis were only recovered from rats of Kifri. On the other hand Trychostrongylus was only recovered from Kalar rats. This could be explained as rats occupy small territories therefore they preserve certain parasites within geographically close populations (Taylor, 1978). In our study male rats were significantly highly infected with 
parasites than females. This is in agreement with the findings of Chaisiri et al. (2010) and Majeed (2016) who reported that male rats were significantly more infected with parasites than female in Thailand and Baghdad respectively. Morales-Montor et al. (2004) mentions that female mammals in general are more resistant to parasitic infections than male due to the genderassociated differences in exposure and immunosuppressive properties of testosterone. Single infection was observed more than coinfected rats in the present study. In Conclusion, Finding of this study reveals that house rats of Garmian region carry both endoparasites and ectoparasites. Some of these parasites are zoonotic and are of great health importance. Single rat can carry more than one pathogen at the same time, this increase the risk of disease transmission. Treatment or eradication of infected rats must be taken into consideration.

\section{References}

1.Al-Ali Z.A. and Jabbr A.K. (2006). Effect of some intestinal parasites on hematological parameters in domestic rodents. Journa of Misan Researches. 2 (4), 198-214.

2.Al-Bajalan M.M. (2018). Prevalence of intestinal cestode infections of conventionally maintained laboratory (albino) and house mice in Kalar district / Sulaymaniyah province. Journal of Garmian University. 6(1), 1-13.

3.Antignano F., Mullaly S.C., Burrows K. and Zaph C. (2011). Trichuris muris Infection: A Model of Type 2 Immunity and Inflammation in the Gut. Journal of Visualized Experiments. 11(2774), 1-5.

4.Chaisiri K., Chaeychomsri W., Siruntawineti J., Ribas A., Herbreteau V. and Morand S. (2010). Gastrointestinal Helminth Infections in Asian House Rats (Rattus tanezumi) from Northern and Northeastern Thailand. J. Trop. Med. Parasitol. 33, 29-35.

5.Franssen F., Swart A., van Knapen F. and van der Giessen J. (2016). Helminth parasites in black rats (Rattus rattus) and brown rats (Rattus norvegicus) from different environments in the Netherlands. Infection Ecology and Epidemiology. 6 (301413), 1-14.

6.Karim A.J and Al-Salihi K.A. (2014). Diagnostic Study on accidental Hymenolepis diminuta Infection in Laboratory Rats in Iraq. MRVSA. 3(3), 33-40.

7.Kia E.B., Homayouni M., Farahnak A., Mohebali M. and Shojai S. (2001). Study of Endoparasites of Rodents and their Zoonotic Importance in Ahwaz, South West Iran. Iran J Public Health.; 30(1-2), 49-52.

8.Majeed S.A. (2016). Prevalence of intestinal parasites in Rattus rattus in some districts in Baghdad/ Iraq. Al-Anbar J. Vet. Sci. 9 (1), 4348.

9.Meshkekar M., Sadraei J., Mahmoodzadeh A. and Mobedi I. (2014). Helminth Infections in Rattus ratus and Rattus norvigicus in Tehran, Iran. Iranian J Parasitol. 9 (4), 548-552.

10.Molan A. and Faraj A.M (2016). Concise Medical Parasitology. 2nd edition. Iraq, P.128200.

11.Morales-Montor J., Chavarria A., De Leon, M. A., Del Castillo L.I., Escobedo E,G., Sanchez E.N., Vargas J.A., Hernandez-Flores M., Romo-Gonzalez T. and Larralde C. (2004).Host Gender in Parasitic Infections of Mammals: An Evaluation of the Female Host Supremacy Paradigm. The Journal of Parasitology. 90 (3), 531-546.

12.Nayyef H.J. (2017). Occurrence of protozoal parasites in Rattus rattus rodent in Baghdad and outskirts, IRAQ. I.J.S.N. 8 (2), 386-389.

13.Pakdel N., Naem S., Rezaei F. and Chalechaleh A. (2013). Survey on helminthic infection in mice (Mus musculus) and rats (Rattus norvegicus and Rattus rattus) in Kermanshah, Iran. Veterinary Research Forum. 4 (2) $105-109$.

14.Parshad VR. Rodent control in India. Integrative Pest Management Review.1999; 4: 97-126.

15.Seifollahi Z., Sarkari B., Motazedian M.H., Asgari Q., Ranjbar M.J. and Khabisi S.A. (2016). Protozoan Parasites of Rodents and Their Zoonotic Significance in Boyer-Ahmad District, Southwestern Iran. Veterinary Medicine International. 1-5.

16. Sharma D., Joshi S., Vatsya S. and Yadav C.L. (2013). Prevalence of gastrointestinal helminth infections in rodents of Tarai region of Uttarakhand. Parasit Dis. 37(2),181-184.

17.Singleton, G.R., Smythe, L., Smith, G., Spratt, D.M., alpin, K. and Smith, A.L. (2003). Rodent diseases in Southeast Asia and Australia: 
inventory of recent surveys. In: Rats, Mice and people: rodent biology and management. ACIAR Monograph No 96. (Ed: G.R. Singleton, L.A. Hinds, C.J. Krebs and D.M. Sparrt) Canberra, Australian Center for international Agricultural Research; Pp.24-29.

18. Siti Shafiyyah C.O., Jamaiah I., Rohela M., Lau Y.L. and Siti Aminah F. Prevalence of intestinal and blood parasites among wild rats in Kuala Lumpur, Malaysia. Trop Biomed. 29(4), 544-50.

19.Smith K.F. and Carpenter S.M. (2006). Potential spread of introduced black rat (Rattus rattus) parasites to endemic deer mice (Peromyscus maniculatus) on the California Channel Islands. Diversity and Distributions, (Diversity Distrib.) 12, 742-748.

20.Soliman S, Marzouk AS, Main AJ, Montasser AA (2001) Effect of sex, size and age of commensal rat hosts on the infestation parameters of their ectoparasites in a rural area of Egypt. J Parasitol 87:1308-1316.
21.Soliman S., Marzouk A.S., Main A.J., Montasser A.A. (2001): Effect of sex, size and age of comensal rat hosts on the infestation parameters of their ectoparasites in a rural area of Egypt. J. Parasitol., 87, 1308-1316.

22.Soulsby, E. J. L. (1986). Helminths, Arthropodes and protozoa of domesticated Animals. 7 eds. Bailliere Tindal, London, U.K. pp: 99-166.

23.Taylor K.D. (1978). Range of Movement and Activity of Common Rats (Rattus norvegicus) on Agricultural Land. Journal of Applied Ecology. 15 (3), 663-677.

24.Terraube J. (2015) "Coping with fast climate change in northern ecosystems: mechanisms underlying the population-level response of a specialist avian predator." Ecography 38.7: 690699.

25. Yokohata Y., Abe H., Ping Jiang Y. and Kamiya M. (1989). Gastrointestinal helminth fauna of japanese moles, Mocera spp. jpn. J. Vet. Res. 37, 1-13. 
Table 1: Types of intestinal and ectoparsites in black rats (Rattus rattus) recovered in this study

\begin{tabular}{|c|c|c|c|}
\hline Parasite type & Infection rate $\%$ & Parasite name & Infection rate $\%$ \\
\hline \multirow[t]{4}{*}{ Nematode } & $20(11 / 55)$ & Trichuris muris & 3.63 \\
\hline & & Capillaria sp. & 3.63 \\
\hline & & Strongyloides sp. & 14.55 \\
\hline & & Trichostrongylus sp. & 1.81 \\
\hline \multirow[t]{2}{*}{ Cestode } & $43.63(24 / 55)$ & Hymenolepis nana & 21.81 \\
\hline & & Hymenolepis diminuta & 32.72 \\
\hline \multirow[t]{3}{*}{ Protozoa } & $25.45(14 / 55)$ & Isospora ratti & 12.72 \\
\hline & & Giardia muris & 5.45 \\
\hline & & Entamoeba muris & 9.1 \\
\hline \multirow[t]{2}{*}{ Ectoparasite } & $7.27(4 / 55)$ & Xenopsylla cheopis & 7.27 \\
\hline & Chi-square $=20.56$ & D.F $=3$ & $\mathrm{P}=0.0001$ \\
\hline
\end{tabular}

Table 2: Prevalence of intestinal parasites in black rats (Rattus rattus) according to sampling areas

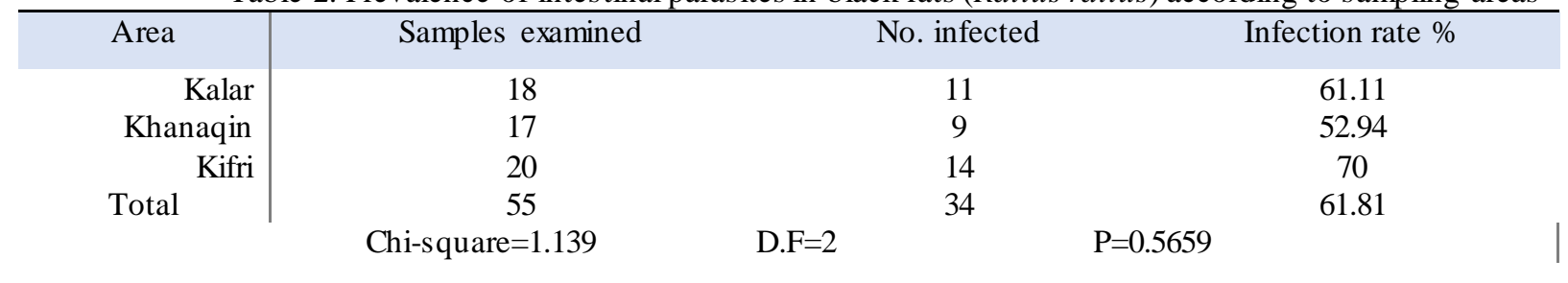

Table 3: Prevalence of intestinal parasites in male and female of Rattus rattus in Garmian region

\begin{tabular}{r|cccc}
\hline Sex of rat & Samples examined & No. infected & Infection rate \% \\
Male & 24 & & 20 & 83.33 \\
Female & 31 & 13 & 41.93
\end{tabular}



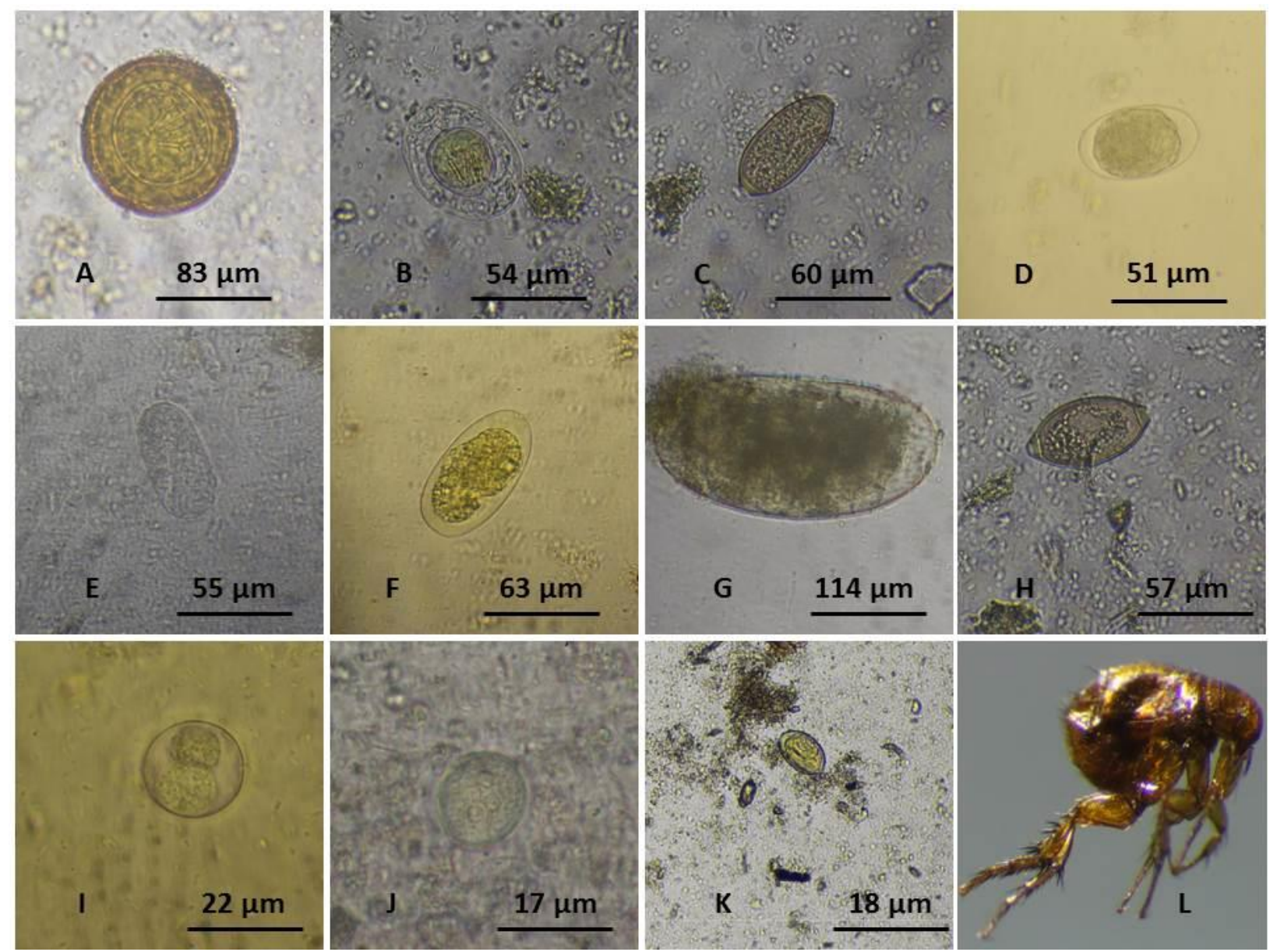

Figure 3: Ova and oocysts identified from intestinal content of black rat Rattus rattus from garmian region. A: Ova of Hymenolepis diminuta (40X), B: ova of H. nana (40X), C: ova of Capillaria sp. (40X), D,E,F: ova of Strongyloides sp. (40X), G: ova of Trichostrongylus sp. (40X), H: ova of Trichuris muris (40X), I: Oocyst of Isospora ratti (100X), J: Cyst of Entamoeba muris (100X), K: Cyst of Giardia muris (100X), L: Adult Xenopsylla cheopis (3.5X). 